NBER WORKING PAPER SERIES

\title{
SORTING OUT JAPAN'S FINANCIAL CRISIS
}

\author{
Anil K. Kashyap \\ Working Paper 9384 \\ http://www.nber.org/papers/w9384

\begin{abstract}
NATIONAL BUREAU OF ECONOMIC RESEARCH
1050 Massachusetts Avenue

Cambridge, MA 02138
\end{abstract} \\ December 2002
}

I am grateful to the University of Chicago Stigler Center and the Houblon-Norman Fund for research support. Parts of this paper draw heavily on "Japan's Financial Crisis: Priorities for Policymakers" that appeared in Fixing Japan's Economy (Japan Information Access Project). I thank the JIAP for permission to reproduce that work. I am grateful to Robert De Young for providing the U.S. figures shown in Table 1. I thank David Atkinson, Tim Callen, Takeo Hoshi, Jakob Lund, Joe Peek, Paul Sheard, Reiko Toritani, and especially Mitsuhiro Fukao for helpful suggestions and comments on earlier drafts of the paper, however, I am responsible for any errors. I also thank the experts who are listed in Table 2 for allowing me to publish their estimates. Forthcoming in Federal Reserve Bank of Chicago Economic Perspectives $4^{\text {th }}$ quarter 2002, pp. 4255. http://www.chicagofed.org/publications/economicperspectives/index.cfm. The views expressed in this document are not necessarily shared by the Federal Reserve Bank of Chicago, the Federal Reserve System or the National Bureau of Economic Research.

(C) 2002 by Anil K Kashyap All rights reserved. Short sections of text not to exceed two paragraphs, may be quoted without explicit permission provided that full credit including, (C) notice, is given to the source. 
Sorting Out Japan's Financial Crisis

Anil Kashyap

NBER Working Paper No. 9384

December 2002

JEL No. G28, G21, G22, O16

ABSTRACT

This paper makes three contributions. First, I report information on the size of the Japanese financial crisis. Drawing principally on work by Fukao (2003) and Doi and Hoshi (2003) I estimate that the current taxpayer liability for losses incurred but yet to be recognized is likely to be at least $24 \%$ of GDP. Second, I explain why it has been so difficult to end the crisis. Third, I sketch the likely ingredients of what will be required to successfully resolve the crisis. The overarching principle is that Japan's banks, insurance companies, and government financial agencies all suffer different problems and require different solutions. But all three sectors are connected, and a failure to tackle concurrently the problems of all three promises to doom any reform plan.

\author{
Anil K. Kashyap \\ Graduate School of Business \\ University of Chicago \\ 1101 East $58^{\text {th }}$ Street \\ Chicago, IL 60637 \\ and NBER \\ anil.kashyap@gsb.uchicago.edu
}




\title{
Sorting out Japan's financial crisis
}

\author{
Anil K Kashyap
}

\section{Introduction and summary}

Over the last decade, the Japanese economy has underperformed dramatically_ growing an average of 1.1 percent per year versus 4.1 percent per year in the previous ten years. At the same time, the country's financial system has fallen into disarray. Recently, the debate over how to address the financial sector problems and the role that this should play in Japan's economic policy have come to the fore. For instance, the International Monetary Fund's (IMF) 2002 Japan country report proposes a four-part program to address the decade long economic slump and to end the current deflation. The first pillar of the program is to "deal decisively with financial sector weaknesses."

In September, the Bank of Japan (2002a) announced an unusual policy initiative, whereby it would begin buying equities that were held by banks. In announcing this decision, the bank pointed to the importance of resolving the nonperforming loan problem. It stated that "in order to resolve the overall problem, a comprehensive and tenacious approach is needed, centering on a more appropriate evaluation of nonperforming loans, promotion of their early disposal, and efforts towards higher profitability on the part of both firms and financial institutions."

The debate came to head when Prime Minister Junichiro Koizumi replaced his financial services minister and promised that he would deliver a plan for the accelerated disposal of banks' bad loans. The new financial services minister, Heizo Takenaka, promptly formed the Financial Sector Emergency Response Project Team to study the bad debt problem, with a promise that the task force would issue an interim report within several weeks and a full report within a month. Yet, when the interim report was circulated in advance of its formal release, the report's analysis and recommendations were heavily criticized by a number of politicians, and the re- lease of the document had to be delayed multiple times. In this article, I explain why a quick resolution to this problem has not been possible. My central theme is that the financial crisis is sufficiently broad and deep that the necessary institutional changes cannot be initiated or implemented immediately. Nonetheless, many of the ingredients of what will be required for a successful resolution of the problem are clear. The overarching principle is that Japan's banks, insurance companies, and government financial agencies all suffer from different problems and require different solutions. But all three sectors are connected, and a failure to tackle concurrently the problems of all three promises to doom any reform plan.

In the first section, I review the macroeconomic factors that have caused the problems that are now evident in the Japanese financial sector. Poor macroeconomic performance is central to the story, and in this environment some strains on the financial system were inevitable. But I show that macroeconomic conditions alone cannot account for the problems. Instead, one must also account for a host of sector-specific considerations. In the next three sections, I review the challenges facing the reform of the banks, the insurance companies, and the government financial institutions. For each of the three, I provide some estimates on the size of the losses and then explain what will be required to stop them from continuing.

Two primary conclusions emerge. First, the likely cost of the financial problems to the taxpayer is huge: My rough estimate of the lower bound for the full cost is approximately 24 percent of Japanese gross domestic product (GDP). Second, the interaction of a number of factors contributes to delaying the resolution of the problems. This delay could easily raise the costs of resolution. 
Role of macroeconomics in the financial crisis

The combination of slow growth and the decline of the aggregate price level have each contributed to Japan's financial crisis. The single most important problem for the financial sector has been the anemic growth of the Japanese economy over the last decade. Figure 1 shows GDP growth over the last 45 years to put recent performance in context. After averaging more than 3.8 percent between 1974 and 1991, growth dropped to 1.1 percent over the last decade. Obviously, if there had been more growth in the 1990s, the financial sector would be in better shape now.

The more challenging question is how much the financial sector problems themselves independently contributed to the growth slowdown. A full answer to this question is beyond the scope of this article, but even without resolving it, it is safe to conclude two things about the interplay between the financial sectors problems and growth.

First, it is implausible to argue that the decline in stock and land prices at the beginning of the 1990s can be blamed for the financial sector problems today. This simple explanation fails because the banks and government financial institutions continue to make losses on new loans today. Therefore, the crisis cannot accurately be described as merely delaying the recognition of bad news. While the asset price collapse may have triggered the problems, it cannot be blamed for their continuation at this point. This is an important conclusion because it suggests that ending the crisis will require substantial changes in the financial institutions' operating practices.

Second, recapitalizing the banks (and insurance companies) would not be a sufficient step to restore growth. The banking problems reflect the poor conditions of their borrowers. Putting capital into banks to make up for past losses would be pointless if the underlying corporate problems are not addressed. As Caballero, Hoshi, and Kashyap (2002) emphasize, the growth problems today cannot be due solely to a lack of solvent financial institutions. There have always been international banks (and insurance companies) operating in Japan, and the number rose substantially as a result of the so-called "Big Bang" deregulation that was completed in April of last year. These foreign firms are solvent but are choosing not to lend much in Japan. So the problem is not just that the domestic
FIGURE 1

Japanese GDP growth 1956-2001

millions

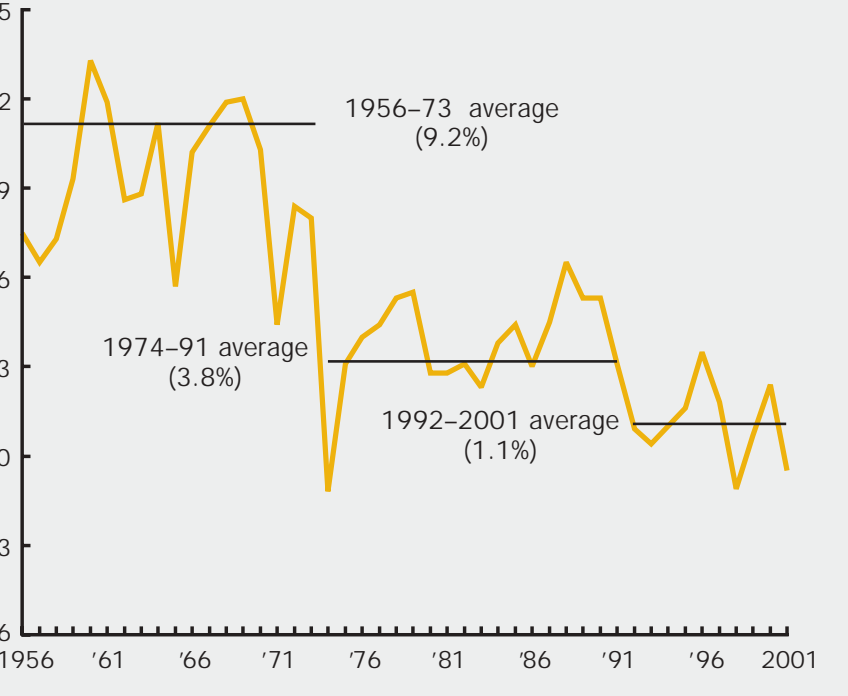

financial institutions are undercapitalized. This is important because it suggests that merely throwing money at the banks will not resolve the crisis.

Determining the appropriate policies to address the problems is difficult. Bank of Japan officials have often alleged that monetary policy is impotent because of the banking problems (see, for example, Hayami, 2002). While it is true that standard open market operations will not be stimulative if banks will not lend, this by no means impairs other types of monetary policy actions. For instance, the proposal by Svensson (2001) for the Bank of Japan to stimulate the economy through foreign exchange intervention is in no way compromised by the banking problems.

On the other hand, without a functioning system of financial intermediation, there are limits as to how successful nontraditional monetary policy actions will be. As growth resumes, government money will be needed to combat some of the insolvencies that are hampering normal financial intermediation. There is a wide range of estimates of the degree of insolvency in the banking industry. But, even without settling the issue of how much it would cost to rehabilitate the banks, it is possible to identify many rescue arrangements that would be counterproductive in virtually all potential scenarios. Later in this article, I highlight many of these poor choices and give some loose bounds on the costs of better alternatives.

The second major macroeconomic problem has been the deflation that has accompanied the slow growth. 
As I explain below, the deflation has played a central role in the problems of the insurance companies. Besides this well-documented and widely discussed effect, the deflation independently has had three pernicious effects on the banking sector.

First, as stressed by Fukao (2003), the deflation squeezes banks profitability. Since nominal interest rates cannot go below zero, there is a floor on the cost of the banks' funds. Even with zero interest rates, depositors may be getting higher real returns than the banks would like to pay. But the banks face competition in lending and, consequently, limits on how much they can charge their customers. With falling prices, banks find it difficult to charge more than 1 percent or 2 percent interest on their loans (since the inflation-adjusted interest burden is much higher). With deflation, the gap between funding costs and lending rates is not sufficient for the banks to make money. If the inflation rate were positive, the banks would have more room to maneuver.

The low nominal rates that are charged to bank borrowers also complicate the problem of regulating the banks. With near-zero interest rates, almost all borrowers can make their required interest payments. Only when a loan matures, and the principal is due, can one gauge the health of the borrower. Since regulators are not necessarily privy to the negotiations that accompany a loan renewal, it can be difficult for them to spot the problem borrowers. Japanese lenders often allow borrowers with no hope of repayment to continue to operate (see Peek and Rosengren, 2002). If interest rates were 3 percent or 4 percent higher, then many of these "zombie" borrowers would soon be unable to service their debts. The regulators would then be able to easily spot the deadbeat borrowers and pressure the banks to cut them off, before more money is lost.

Finally, the deflation has meant that borrowers who took out long-term loans at historically low rates of interest ( 3 percent or 4 percent) have seen the inflationadjusted burden of their debt grow. This is the converse of the more typical phenomenon, whereby borrowers benefit from unexpected jumps in inflation at the expense of lenders. One of the clear benefits from a more expansionary monetary policy would be to reverse the increasing debt burdens.

\section{Banking sector problems}

I begin the sector-specific analysis by analyzing the condition of the Japanese commercial banks. The most thorough, up-to-date analysis of banks available in English is Fukao (2003). Panel A in table 1 reproduces his key figures. As he stresses, the banking industry has not had a net operating profit since fiscal year 1993 (table 1, row G). Until late in the decade, the banks offset these losses by recognizing capital gains on long-held stocks and land. But at this point, there is little more that can be squeezed from these sources. As table 1, row I shows, since 1995 the banks have recorded net losses in more years than not. Cumulating the loan loss figures in table 1 (row F) shows that the banks have recorded losses of roughly $¥ 83$ trillion (16.5 percent of current Japanese GDP) since 1992. ${ }^{1}$ According to Japan's Financial Services Agency (FSA), this includes over $¥ 32$ trillion in outright write-offs! Yet the losses are expected to continue for the foreseeable future.

As noted earlier, these losses are too large and persistent to be blamed solely on the rapid decline in asset prices at the beginning of the 1990s. Indeed, as the Bank of Japan (2002b) has pointed out, since 1990 the banks have disposed of more than $¥ 90$ trillion, which amounts to 80 percent of the increase in loans between 1986 and 1990. Thus, it is implausible to suggest that the continued losses can be attributed to misguided lending decisions during the late 1980s. Rather, they are indicative of deeper underlying problems facing the financial services industry.

There are two complementary ways to analyze the banks' current problems that ultimately lead to similar solutions about what might be done to reverse their decline. One focuses on the banks' current costs and revenue structure, while the other looks at the economic forces operating in the industry.

\section{Flow profitability problems}

The first approach puts the emphasis on the failure of the banks to generate enough revenue on their loans and other assets to cover their funding and operating costs. To put this in perspective, the second panel of table 1 reports U.S. data that are roughly comparable to Fukao's data for Japan. ${ }^{2}$ Despite the data limitations, the comparison clearly shows that the Japanese banks suffer from several structural problems. One is the lack of profitability of their lending operations. The Japanese banks' interest margin relative to assets has hovered around 120 basis points. The U.S. figures (which include both fees associated with the loans and interest revenue) are roughly three times as high-far too big a difference to be attributable to the differences in measurement.

Fukao notes that if the deflation were to stop, then the banks could raise nominal interest rates without raising the real interest burden for borrowers. But there are limits to how much this could be expected to help. For instance, assuming, optimistically, that when the deflation ends the banks could raise their interest margin by 1 percentage point (say by increasing lending rates by 2 percent and deposit rates by 1 percent), this would add only another $¥ 5$ trillion in interest margin. 


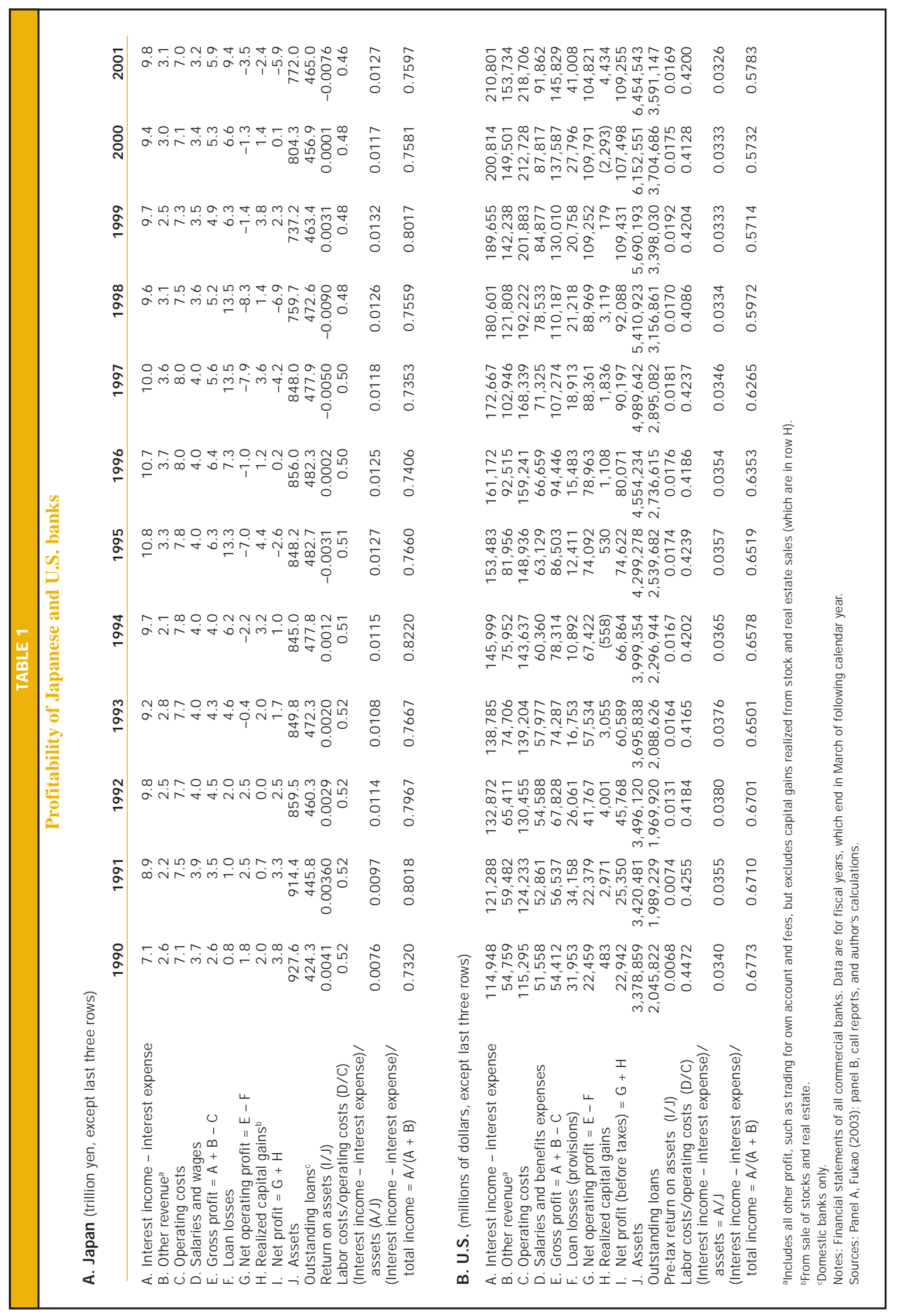


While this might be enough to stop the banks' losses, they would still be far less profitable than their U.S. counterparts.

Another problem is the Japanese banks' high labor costs. The banks have made some progress in reducing salary and wage expenses from roughly 52 percent of operating costs to 46 percent. Although anecdotal reports of overpaid and underutilized bank staff still abound, the Japanese banks likely will have to increase pay to some workers if they want to upgrade competency levels in order to increase fee- and commissionbased income. It is doubtful therefore that the Japanese banks can push their salary expenses all the way down to the U.S. level of about 42 percent of operating costs.

Finally, while not evident in the table, it is also well known that the Japanese banks underinvested in technology during the last half of the 1990s. This has long been recognized as a problem. For example, although a condition of government-provided funds offered to the banks in 1999 was that the banks had to improve efficiency and reduce costs, the general cutbacks in investment were not to be extended to investment in computing and automation. Still, more than three years later, the concerns about poor computing operations persist.

The failure of the Mizuho Group's computers that occurred on the first day that the bank began operating could hardly have been more symbolic. Due to poor integration of the three merging banks' antiquated systems, the new bank's computers failed. As a result, the ATM network was unavailable, a number of automatic payments were not made, and many customers were double-billed for credit card transactions. ${ }^{3}$ The Bank of Japan subsequently had to order Mizuho to upgrade its computing systems.

Fukao reports that the main funds payment system used by Japanese banks (zengin) is unable to handle twobyte codes, and hence cannot transmit customer names and messages in kanji (characters). This is one of the reasons why convenience stores (that have typically installed more sophisticated technology) have won customers that would like to make an occasional electronic payment at the banks' expense. The zengin system is scheduled for an upgrade in April 2003, but the banks will have to do much more if they want to match the technological efficiency of many of their global competitors.

\section{Japanese banks' limited comparative advantage}

The alternative (and complementary) approach to analyzing the banks' profitability problems is to look at their product mix and ask which lines of business can be expected to earn normal rates of return? The Japanese banks are among the largest in the world in terms of assets. For instance, Agosta (2002) reports that the Mizuho Group and Mitsubishi Tokyo Financial Group are the first and third largest in the world, respectively, and that 19 of the largest 100 banks in the world are Japanese. Yet, there are few if any product lines for which the Japanese banks are world leaders. I find no examples where Japanese banks and their global rivals have competed for business on a level playing field and the Japanese banks have emerged as market leaders. Instead, the recurring pattern is that Japanese banks are later to enter markets or offer new products and, consequently, their profitability lags.

The low levels of fee income alluded to earlier are a particularly important reflection of this problem. As Hoshi and Kashyap (2001) note, for the Japanese banks in aggregate, fee and commission income as a percentage of total income was essentially identical in 1976 and 1996; the U.S. banks during this period increased their percentage of fee and commission income by twoand-a-half times. This disparity partially was attributable to regulation that handicapped the Japanese banks. For instance, until 1998 the banks were simply barred from many activities, such as over-the-counter derivatives transactions, brokerage activities, and underwriting.

But even after the full deregulation that was completed on April 1, 2001, the gap persists. The last row in panel A of table 1 shows that the Japanese banks continue to make roughly 76 percent of their income (excluding capital gains) from their lending operations. In contrast, U.S. banks make only 58 percent of their income from this low margin activity; instead they bring in a much higher percentage of high margin fee and commission businesses. ${ }^{4}$ Since these nontraditional products and the associated revenue streams are central to the business strategies of most global banks, this deficiency is a huge problem for the Japanese banks. Without making comparable profits in these areas, it is hard to see how the Japanese banks could ever reach the same rates of return as their competitors.

One way to address this problem would be for Japan's major banks to scale back on their operations and to focus on niche needs of Japanese customers (mostly small and medium-sized businesses). Japanese banks might arguably be better than foreign banks operating in Japan in this product line. The loan demand of these customers, however, is much lower than the assets of the current banking system; therefore, shifting in this direction in order to raise profitability would imply considerable downsizing. But downsizing would involve the release of many mid-career and upper level managers, who might face significant hurdles in becoming reemployed.

A final, further impediment to the banks' profitability is the difficult competition that they face from 
subsidized government financial institutions. The postal savings system poses a particularly big problem. As Fukao asks, how can the private banks make profits when Japan's government-sponsored postal savings system has 40 times the number of offices of the largest banking group, pays roughly the same rate on deposits as the banks, and charges no maintenance fees? The extra convenience of the postal accounts, combined with the government guarantee of deposits, represents a major challenge for the banks.

The government-subsidized Housing Loan Corporation (HLC) also compromises the banks' ability to make money through home mortgage lending. The HLC receives subsidies (as described below) from the government and passes these savings on to their customers. The HLC makes about 40 percent of all home mortgages. Fukao (2003, table 8) shows that the HLC loans have rates that are substantially lower than those offered by private banks, despite typically having longer maturities. Moreover, the HLC loans come with no prepayment penalties (unlike typical Japanese bank mortgages).

These kinds of government-sponsored financial institutions will have to be reined in if Japanese banks are to regain profitability. This is widely recognized outside Japan. For instance, the Bank for International Settlements in its 2001 annual report (2002, p. 133) notes that one of the contributing factors to the banks' profitability problems is the "strong competition from government sponsored financial institutions." The IMF 2002 country report goes further and says that the (p. 3) "exit of non-viable banks and a scaled down role of government financial intermediation are necessary to improve bank profitability."

Yet, despite making it a priority to privatize the postal savings system and otherwise reform many government agencies, the Japanese government has encountered strong resistance to its efforts to address this problem. The postal savings system and the government's home lending program are popular with the public. Furthermore, the public has not been convinced that these programs in fact are contributing to the banking troubles. Given the public support, and the role that the postal savings system plays in the Fiscal Investment Loan Program (described below), it is not too surprising that many politicians have fought the Koizumi administration's reform efforts, delaying a full-fledged attack on the banking problems. However, without some adjustments to these reform programs, the banks' problems are likely to reappear even if they were to regain solvency.

\section{How much would recapitalization cost?}

Assuming that the banks could figure out how to resume making profits, the next obvious question is how much would it cost to make the banks solvent? I review first the three main problems that plague attempts to arrive at an estimate, before reporting the range of estimates currently made by market participants.

The first problem with this type of exercise is determining the current level of losses associated with existing loans. The banks in Japan are known for their propensity to under-reserve against recognized bad loans. For instance, they have set aside reserves sufficient to cover between 40 percent and 60 percent of bad loans over the last few years, whereas U.S. banks tend to hold closer to 160 percent in reserves (Fukao, 2003). By Fukao's estimate, the banks are currently short at least $¥ 7$ trillion in loan loss provisions.

Then there is the larger problem of deciding how many additional loans are in fact already bad, but have not been revealed as such. Almost all analysts agree that there are many more bad loans than the banks have acknowledged. But there is considerable disagreement over the size of the under-reporting. For instance, Credit Suisse First Boston analysts estimate the ratio of problems loans for the seven major banks to total loans to be just about 27 percent, roughly four times the disclosed figure. ${ }^{5}$ Meanwhile, Goldman Sachs estimates that all bad debts (for the entire banking system) are three times as high, $¥ 236.6$ trillion (38.1 percent of all system loans)! ${ }^{6}$

Translating the figures on nonperforming loans into estimates of taxpayer exposure requires a further step of netting out collateral and other bank reserves. But carrying out this netting is challenging when the underlying environment is still unstable and the reported levels of problem loans keep rising. The ratio of nonperforming to total loans has been steadily rising among the smaller banks in Japan. A first sign that disclosed losses are catching up to actual bad loans will be when the ratio of nonperforming loans to total loans levels off. In the meantime, much of the discrepancies in estimates across analysts arise because of different assumptions about under-reporting (and the methods used to net the losses against other assets).

A second issue is the quality of the other parts of the banks' balance sheets. Two items in particular are treated in ways that overstate the apparent health of the banks. One is that bank capital is permitted to include tax credits against future profits. The figures for the largest banks suggest that about 35 percent of shareholders' equity is made up of these deferred tax credits for loan losses. ${ }^{7}$ But for these credits to be of any value, the banks must quickly regain profitability once the loan losses are recognized: Tax loss credits expire five years after the bad loans are actually worked out, so many of the existing credits will expire before they can be claimed. ${ }^{8}$ 
Another problem is that the banks hold a significant amount of insurance company debt (usually in the form of subordinated loans or surplus notes). As I discuss in the next section, the life insurance companies also tend to hold large amounts of subordinated bank debt and stock. Many of the life insurance companies are also in a very precarious financial position. This "double gearing" makes the banks and the insurance companies each look to be better capitalized than is in fact the case. ${ }^{9}$

The ownership of life insurance securities is also part of the broader tendency for Japanese banks to own corporate equities. Fukao estimates that as of March 2002 , the banks held equities worth roughly $¥ 34.4$ trillion, which was substantially larger than their true capital (by a factor of seven if one accepts Fukao's adjustments to correct for the overstated value of the deferred tax credits, the under-reserving of bad loans, and the preferred shares loans from the last public injection of capital in March 1999). Thus, the banking sector's value is quite sensitive to changes in share prices; based on Fukao's figures, the decline of the Nikkei from 11,025 on March 31 to 9,383 at the close of September 30 would have wiped out all the banks' private equity (assuming they had not bought or sold any in the interim). Accordingly, the size of the mismatch between the value of banks' assets and liabilities at any point in time depends importantly on the level of stock prices at the time.

The Bank of Japan recently announced that it was prepared to buy securities from the banks at market prices. If the banks do accept this offer and sell at prevailing market prices, this policy would have very little short-run impact. The banks would still have to accept any losses that were embedded in their portfolios and doing so would erase their capital by the amount of the losses. The only advantage for the banks would be that they could opt to significantly reduce their equity holdings without necessarily pushing prices down.

Conversely, if the Bank of Japan were to pay a premium for any securities bought from the banks, then the premium would increase the banks' capital. But, the outline for the stock purchasing plan announced by the Bank of Japan (2002c) states that the prices will be at the market prices defined as "the lesser of the volume-weighted average price or the day's closing price." More importantly, the total amount purchased will be limited to $¥ 2$ trillion. Therefore, even if the prices were substantially above the market price, the potential transfer to the banks would be quite limited.

Finally, the amount of the funding needed to eliminate the banking sector's insolvency will depend on the macroeconomy (for all the reasons discussed ear- lier). The cost to the U.S. taxpayers of the U.S. banking crisis in the early 1990s turned out to be well less than 1 percent of (then current) GDP, because of the phenomenal growth of the economy over the 1990s. It is very unlikely that Japan will experience anything like that during its recovery, but differences of opinion over the likely path of the economy over the near term further contribute to the dispersion of estimates.

Given all these caveats, it should come as no surprise that different observers reach fairly different assessments about the amount of funding that would be required to make the banks solvent. Table 2 shows the estimates of many of the leading economists and bank analysts as of August 2002, collected by direct correspondence with the experts. They were each asked to report their estimates of the difference in the market value of assets and liabilities of the Japanese banks (as of August 1, 2002); as indicated in the table, several of the responses cited previously published estimates of slightly different quantities (for example, the value of all problem loans or losses at major banks only).

The most optimistic figure would suggest losses of less than $¥ 12$ trillion (2.4 percent of Japanese GDP); this would be the case if the baseline ING Securities estimate were adjusted to take care of the phantom tax credits that overstate capital by roughly 35 percent. The Goldman Sachs and Lehman Brothers estimates suggest losses that are roughly three times as high. Regardless of which numbers one believes, it is clear that the losses for the taxpayers will be substantial.

These figures and the foregoing discussion also explain why Takenaka's Financial Sector Emergency Response Project Team posed such a threat to the opponents of reform. The task force's initial recommendations were reported to have centered on reducing the length of time that could be used to claim tax credits as part of banks' capital, tightening loan assessment standards, and forcing increased provisioning for losses. Significant changes in any of these directions would severely impact banks' capital and likely could push some (or nearly all) of the major banks below the mandated level of capital. It is not surprising, therefore, that this possibility triggered intense criticism of Mr. Takenaka and his plan.

But, as the estimates in table 2 show, regardless of whether the capital deficiency is recognized by the regulators and acknowledged to the public, the private sector analysts are unanimously of the view that the banks are bankrupt— by a significant amount. This suggests that barring a miraculous economic recovery that no one is forecasting at this time, the banks will eventually be forced either to close or to raise more capital. 


\begin{tabular}{|c|c|c|c|}
\hline \multicolumn{4}{|c|}{ TABLE 2} \\
\hline \multicolumn{4}{|c|}{ Experts' estimates of the insolvency of the Japanese banking system } \\
\hline Analyst & Firm & Estimate & Comments \\
\hline & (date of estimate) & & \\
\hline David Atkinson & $\begin{array}{l}\text { Goldman Sachs } \\
\text { (October 31, 2001) }\end{array}$ & $\begin{array}{l}¥ 70 \text { trillion of net loan losses } \\
\text { based on March } 2001 \text { loans } \\
\text { ( } ¥ 18.7 \text { trillion for the major } \\
\text { banks) }\end{array}$ & $\begin{array}{l}\text { Large bank losses represent } \\
161 \% \text { of capital adjusted for } \\
\text { tax loss carry forwards and } \\
\text { public money. }\end{array}$ \\
\hline Robert Feldman & $\begin{array}{l}\text { Morgan Stanley } \\
\text { (August 2002) }\end{array}$ & $¥ 22$ trillion & $\begin{array}{l}\text { Intended to be a lower bound } \\
\text { for additional taxpayer exposure. }\end{array}$ \\
\hline James Fiorillo & $\begin{array}{l}\text { ING Securities (Japan) } \\
\text { (August 2002) }\end{array}$ & $\begin{array}{l}¥ 19.9 \text { trillion in net loan losses, } \\
-¥ 2 \text { trillion in unrealized capital } \\
\text { gains }\end{array}$ & $\begin{array}{l}\text { Capital (as reported without } \\
\text { adjustments) } ¥ 16.2 \text { trillion }\end{array}$ \\
\hline Yukiko Ohara & $\begin{array}{l}\text { Credit Suisse First Boston } \\
\text { Securities (Japan) Limited } \\
\text { (July 2002) }\end{array}$ & $\begin{array}{l}¥ 21.8 \text { trillion in required credit } \\
\text { costs for the major banks }\end{array}$ & $\begin{array}{l}\text { Estimated non-performing loans } \\
\text { for the major banks } ¥ 121.9 \\
\text { trillion }\end{array}$ \\
\hline Paul Sheard & $\begin{array}{l}\text { Lehman Brothers } \\
\text { (August 2002) }\end{array}$ & $\begin{array}{l}\text { "To restore the balance sheet } \\
\text { health and credibility of the } \\
\text { banking system would probably } \\
\text { require } ¥ 30 \text { to } ¥ 50 \text { trillion." }\end{array}$ & $\begin{array}{l}\text { Notes that the deposit insurance } \\
\text { fund has } ¥ 49 \text { trillion of untapped } \\
\text { capacity. Thus, infrastructure and } \\
\text { budgeting are in place to act if } \\
\text { there were political will. }\end{array}$ \\
\hline Reiko Toritani & $\begin{array}{l}\text { Fitch Ratings } \\
\text { (August 2002) }\end{array}$ & $¥ 23$ trillion for the major banks & $\begin{array}{l}\text { Adjusting the stated value of equity } \\
\text { for the major banks as of March } \\
2002 \text { to account for fictitious } \\
\text { tax credits, public funds, and } \\
\text { unrealized gains implies a market } \\
\text { value of essentially zero. }\end{array}$ \\
\hline
\end{tabular}

This conclusion leads to two criteria that can be used to judge policy proposals regarding bank recapitalization. First, it may be helpful to distinguish between proposals that do and do not facilitate the downsizing and consolidation of the banking sector. If one accepts the earlier analysis, it is quite likely that the road to profitability will come through focusing on more profitable activities and shedding assets. Under this view, the total level of capital to be committed to the industry should be determined by the level needed to support the long-run size of the industry, not necessarily its current size.

Second, since money to bail out the banks is limited, any refinancing proposed should be done in a focused fashion. In particular, if exit of some banks is inevitable, then it is poor policy to prop up banks that will soon go out of business. Past recapitalizations in Japan did not adhere to this rule, but featured across-the-board rescues, whereby some of the money was wasted on dying banks.

These mistakes could be avoided if more market signals were used to decide which banks merited funding. Banks that cannot attract private financing as part of their recapitalization might be given lower priority than those that can. This type of selective rehabilitation would lead to the best banks being rebuilt. The resulting banking sector would be more efficient at directing funds to deserving borrowers.

\section{Problems with the life insurance sector}

The life insurance companies comprise the second largest part of the financial system. As of March 2002, the ten major private insurance companies had assets of roughly $¥ 150$ trillion (30 percent of GDP). Most insurers are mutual companies so that their shares are not traded on exchanges, but as explained earlier their financial linkages with the rest of the financial system are extensive. For instance, at least 10 percent of the equity of each of the major Japanese "city banks" (that is, those that are large and globally active) is owned by insurance companies; as of March 2001, insurance companies owned $¥ 5.4$ trillion of bank equity and $¥ 5.1$ trillion of subordinated bank debt. Thus, it is necessary to recognize that the health of the insurers is intimately connected with that of the banks.

\section{Similarities with the banks}

The problems of the life insurance companies resemble those of the banks in three respects. First, they too have made bad loans. However, the scale of the insurers' lending mistakes is quite different. As of March 2002, the ten majors had disclosed $¥ 568$ billion in 
loans to distressed firms. This amounts to less than 2 percent of their total loans. Moreover, they had reserves against these loans of over 70 percent. ${ }^{10}$ Thus, even if there is substantial under-reporting of the problem loans, the bottom line of the insurers is much less likely to be affected.

Second, the insurers have very significant exposure to the changes in the aggregate stock market. The Daiwa Institute of Research (DIR) produces company by company estimates of the levels of the stock market at which unrealized gains on securities disappear. ${ }^{11}$ The critical value of the Nikkei 225 stock index for the different firms is between 8,400 and 12,500, with an average of 10,880. DIR estimates that as of March 31,2002 , when the Nikkei was at 11,024.94, the aggregate unrealized gain on stocks was approximately $¥ 1.88$ trillion. Fitch makes a similar calculation using cutoff values for the Tokyo Stock Price Index (TOPIX). With the TOPIX at 903 (as of October 1), the Fitch estimates imply that nine of the ten major insurers would have unrealized losses in their equity portfolios. ${ }^{12}$

Third, the insurance companies also face acute competition from the government-sponsored financial institutions. In their case, the key competitor is the postal life insurance program. The postal insurance program sells about one-third of the life insurance in Japan. While the same convenience advantage accrues to the postal insurance program as to the postal savings program, the pricing of the insurance does not seem to be as distortionary. However, the premiums paid into the postal insurance accounts are largely recycled through the fiscal investment loan program, as described below.

\section{Excessively optimistic estimates of returns}

Despite these similarities to the challenges facing the banks, the fundamental profitability problem for the private insurers is unique and largely self-induced. Primarily, they have been crippled by their overly optimistic assessment of anticipated investment returns. For instance, as of 1992, the life insurance companies were all selling lifelong annuities that promised to pay a return of 5.5 percent. As interest rates fell, a gap opened between what the insurers had promised to pay and what they could expect to earn. This difference is referred to in the insurance industry as the "negative carry" (or "spread").

As of March 2002, the insurers had a disclosed negative carry of $¥ 1.25$ trillion. This flow loss can be compared with the profits of roughly $¥ 3.3$ trillion from the other parts of their business. Because the disclosed carry omits unrealized capital losses, these figures are likely to provide an overly optimistic reading of the firms' health.
The regulatory assessment of the industry is based on the concept of a solvency ratio, which is intended to measure the extra capital that insurers are expected to hold in order to make good on their promised payouts. The formula for calculating the margin is complicated and involves estimating the risks from insurance underwriting, interest rates, asset management, and business administration and then comparing the risk with the insurer's ability to pay (based on the quality of its assets). ${ }^{13}$ Insurance companies around the world are measured by this yardstick, and since 1999 Japanese insurers have been subject to prompt corrective action whenever their solvency margin fell below 200 percent. The ten major insurers all reported solvency margins in excess of 400 percent as of March 2002.

As with the banks, there are dramatic differences between the officially reported solvency margins and more realistic estimates. Fukao (2003) highlights three problems with the standards used in calculating Japanese solvency margins (compared with practices in the U.S.). First, the Japanese supervisors use lower risk weights than in the U.S. Second, the ability to pay is inflated by including assets that have no liquidation value. Finally, the ability to pay ignores unrealized capital gains and losses.

Fukao finds that making these corrections to move the Japanese figures toward the U.S. standard dramatically lowers the margins. Using March 2001 data, when the Nikkei 225 average was roughly 13,000, his estimates show that three companies' ratings (Mitsui Life, Asahi Life, and Sumitomo Life) were all below the critical level of 200. As reference, the official ratios for all three were in excess of 490.

Ex post, Fukao's adjustments seem to do a good job of predicting which firms will fail. All the major life insurers that have been distressed since mid-2000 (three that went bankrupt and one that required a significant equity injection by a foreign partner) showed similarly low adjusted-solvency margins. With the Nikkei now markedly lower than its March 2001 level, it is likely that the next weakest surviving firms (Yasuda, Meiji, and Daiichi) are also near the threshold.

\section{Bailing out the life insurance companies}

With the banks there is a strong presumption that depositors must be protected (to prevent runs and contagion). No similar argument can be made for insurance companies. The insurers would be viable if they simply had more realistic promised payout rates. The obvious solution is to have the companies declare bankruptcy and force the policyholders to take a reduced rate on their investments. 
Political economy concerns regarding an insurance company write-down should be less of a problem than if a similar remedy were proposed for the banks (that is, forcing the bank depositors to absorb the banks' losses), the important difference being that the policyholders taking a haircut would be the ones that had benefited from the overly generous payments. For the banks, the depositors generally did not receive the loans that are now unrecoverable. This difference probably explains why so many prominent insurance companies have actually declared bankruptcy: eight major ones between April 1997 and April 2002. In contrast, only three of the large banks failed during this time.

The fact that the fundamental problem is so easily diagnosed is further confirmed by the behavior of foreign competitors. Since the Big Bang deregulation, foreign firms have raced in to partner with the insurers. For instance, Hoshi and Kashyap (1999) note that seven of the life insurance companies entered into significant alliances with foreign companies in 1998 and early 1999. This outnumbered the number of deals by the banks (six), despite the fact that there were vastly more banks looking for partners. Instead, the banks mostly worked out deals with other Japanese firms. One interpretation of this contrast is that the insurers are judged by potential investors as having much more underlying value than the banks.

Collectively, these observations can be summarized in three propositions. First, the continued functioning of the insurance markets does not require that the government put money into the sector. Second, there do not seem to be overwhelming political constraints that prevent market solutions (that is, bankruptcy) from working. Third, foreign firms see some underlying value in the sector, so that perhaps entry or acquisitions can be expected if the bankruptcies continue.

Thus, viewed in isolation, there seems to be no reason to provide public money to rescue the insurers. The weaker ones would be expected to fail, but the fallout from this would be limited. The fact that the Life Insurance Policyholders' Protection Corporation of Japan (the government bailout fund) is broke from past payouts reinforces this possibility.

However, the banks and insurance companies are linked through their double-gearing. Fukao estimates that the banks hold roughly $¥ 2.2$ trillion of the surplus notes and subordinated debt of the insurers. Whenever the insurance losses are recognized, the banks will have to take their share of these losses. Unless the government were to purchase these securities as part of the bank clean-up, the banks would be at risk for requiring more capital. At the very least, planning how to decouple the two should begin and the banks and in- surance companies should be encouraged to work to sever their linkages.

Most outside analysts take it for granted that the double-gearing is dangerous. For example, the Bank for International Settlements' 2001 annual report strongly criticized this practice (2002, p. 135), saying "these interlinkages increase systemic risk, particularly considering the weaknesses in the Japanese insurance sector."

However, Japanese government policymakers do not seem to recognize these risks. For instance, Shokichi Takagi, Commissioner of the FSA, responded to the BIS criticism saying that "the nature of the risks is different between insurance companies and banks. ... As far as the conventional approach is concerned, the nature of risks is different and there[fore] the cross-holding of equity is not a big deal. So-called double-gearing is not excluded at this point, as the nature of the risks is different." 14 Thus, one big impediment to addressing this issue is the regulatory stance of the FSA.

\section{Government-sponsored agencies}

Finally, I consider the impact of the government financial institutions. These organizations engage in a host of activities, ranging from offering home mortgages and providing life insurance and savings accounts to financing highway development. They are relevant to our discussion for two different reasons. The first is that many of these agencies are losing money and will ultimately require a taxpayer bailout. The money that will be spent here constrains the funding that is available for the insurance and banking restructuring. Second, these agencies' losses are often related to operating practices that limit the viability of complementary private sector firms. Thus, one important public policy issue is whether these government agencies should continue to compete with the private sector firms.

Gauging the size of taxpayer exposure is very complicated, since financial disclosure is poor and many of the assets of these institutions are obligations of other government institutions. A typical transaction starts with a home loan extended by the HLC. The HLC would raise the money to provide the loan by issuing debt that is bought by the public and other government financial institutions. Thus, determining the full taxpayer exposure will potentially involve looking at the financial condition of several organizations.

To do this systematically, I rely on the recent work of Doi and Hoshi (2003). They focus on the financial condition of the fiscal investment loan program (FILP). The FILP is often called the Japanese government's second general account budget. Historically, most of the money in this program was collected from people's deposits in the postal savings program. The ubiquitous 
branching system of the Post Office, combined with branching and other restrictions that prevailed until recently for commercial banks, led many Japanese to keep their wealth in postal savings accounts. The money in these accounts was then turned over to the Trust Fund Bureau of the Ministry of Finance (MOF) and loaned out as MOF officials saw fit through the FILP. The ability to direct funds to favored projects, which are not easily monitored, makes this process very convenient for political purposes.

Thus, one can think of the FILP money as funding the financial institutions, as well as providing significant money to local governments and many other programs. Importantly, these programs are not integrated with the central government's budget, so that the obligations for these programs are not part of the government's gross debt. In total, roughly $¥ 418$ trillion (84 percent of GDP) flowed through the system during the fiscal year ending in March 2001. By assessing the health of the FILP-dependent borrowers, we can not only learn about the condition of key government sponsored financial agencies, but also about the other hidden losses that may be handed to the taxpayers.

In parsing the figures, it is instructive to separate the condition of the financial institutions and other special purpose agencies (that I collectively refer to as the FILP agencies) from those of the local governments. The two differ both in the nature of the accounting information that is available and in the role that they play in the economy. This leads to different levels of confidence in our estimates of losses and potentially different public policy implications. Thus, I follow Doi and Hoshi and report separate estimates.

\section{Quantifying losses for the FILP agencies}

To see the problems for FILP agencies, we can revisit the HLC example described above. If all the underlying assets are solid (in this case the assets associated with the property loan), then the intermediate transactions are irrelevant. The HLC debt can be repaid using the proceeds from the loan and this means that the government financial institutions that bought the debt can pay back their depositors. In other words, the relatively low net position of the government is what matters.

If the HLC loan is not performing, then the situation becomes more complicated. In this case, the HLC debt will not be fully paid with the proceeds from the loan. But it is unlikely that the government will default on the HLC bonds, so new funds must be raised to pay the bond holders (and ultimately the depositors of financial institutions that bought the debt). Effectively this means that the gross amount of debt (that owed by the HLC and the government financial institutions) is the relevant figure for determining the government's obligations.

The quantitative gap between the gross and net figures for Japanese government debt is huge. Japan has the highest level of gross debt relative to GDP of the G-10 (Group of Ten) countries and the lowest level of net debt. Thus, one's perspective on the quantitative importance of any FILP losses (which are outside of the official debt calculation) requires further judgment about the quality of the central government's assets. A full analysis of the entire budget is beyond the scope of this article, so I will tackle the narrower question of the FILP losses, which turns on the asset quality in the FILP transactions.

Doi and Hoshi point to three recurring problems that suggest asset quality is low. First, there are three cases (most notably the HLC) where past losses are recorded on the agency books as an asset. The agencies rationalize this by arguing that the losses were sudden and it would be misleading to immediately recognize them; instead they are expected to slowly eliminate these losses by reducing their capital. To correct for this inaccurate reporting, the first step in the analysis is to immediately count the losses. By doing this, Doi and Hoshi write down the capital of these three agencies by $¥ 0.5186$ trillion.

A second more widespread problem is that many agencies acknowledge that their loan losses exceed their reserves. Doi and Hoshi estimate that this practice is employed by 22 of the 58 recipients of FILP funds. In total, they estimate $¥ 8.2$ trillion in recognized bad loans have yet to be provisioned for. Of course, there is the additional problem that there are likely to be many more bad loans that have yet to be uncovered.

A third pervasive problem is the overvaluation of physical assets. The Public Highway Corporation and several other agencies do not properly account for depreciation. Instead, depreciation of assets is only recorded when operational revenues are high enough to count the depreciation and still show "profits" on the financial statements. A related problem is that the value of long-term assets is generally based on the historical acquisition costs. For land purchased in the 1980s, this will greatly overstate the current market value. Doi and Hoshi attempt to correct for market value changes and depreciation of the 12 FILP agencies that have a high percentage of physical assets relative to total assets. (These turn out to be agencies that are involved in urban development or infrastructure provision.) It appears that losses of roughly $¥ 11.4$ trillion are uncovered once these corrections are made.

Finally, there is the problem that many FILP agencies are making flow losses that need to be covered by taxpayers. Since fiscal year 1999, the agencies 
have been required to make a discounted present value calculation of the gap between their revenues and costs. Of the 33 agencies that report the figures for March 2001, 28 expected costs to exceed revenues. Moreover, Kikkawa et al. (2000) find that agencies have been extremely optimistic in their revenue forecasts. The March 2001 estimates suggest that net losses will total ¥11.7 trillion, and this is certainly a lower bound on the likely losses.

Doi and Hoshi do a careful agency by agency calculation of how all of the aforementioned problems will affect taxpayers. By disaggregating in this way, they can allocate any insolvency that is present in the agencies to the government and any other stakeholders. Moreover, they compare losses to the amount of capital that is already on the books to figure out how much more money will have to be provided. They arrive at a (intentionally conservative) cumulative estimate of $¥ 35.8$ trillion (7 percent of GDP) for the taxpayer exposure from the operations of the FILP agencies.

\section{Other FILP losses}

However, the full taxpayer bill also depends on the other non-agency loans. As of March 2001, about ¥87 trillion of FILP funding was steered to local governments. Assessing the quality of these loans is difficult since local governments are not required to produce balance sheets or other financial statements that would allow a direct estimate of the quality. However, the fact that many local governments have substantial debts and are running very small surpluses (or outright deficits) suggests that some default on the debt is possible.

Doi and Hoshi run a variety of simulations to assess the local governments' ability to pay versus their debt levels. The simulations differ according to the assumptions that are made about the growth rates of future deficits and tax revenues. The locals had FILP obligations of $¥ 125.5$ trillion as of March 2001. The resulting estimates of the size of the losses borne by taxpayers cluster between $¥ 30$ trillion and $¥ 40$ trillion一 importantly, this accounts for the fact that the FILP is not the only creditor of the bankrupt governments and nets out all collateral that is available.

\section{Implications for government financial institutions}

Combining all the estimated FILP losses, Doi and Hoshi's preferred estimate of likely FILP losses is $¥ 78.3$ trillion (just over 15 percent of GDP). The sheer size of these potential losses no doubt makes politicians hesitant to publicly acknowledge them. However, without building some public recognition of the losses, it will be difficult to undertake fully the necessary reforms. In the meantime there are several intermediate steps that would be useful.
One goal would be to stem taxpayer losses by reducing the flow of FILP money to insolvent borrowers. A FILP reform was enacted in April 2001 that could lead to this outcome. As part of the reform, government agencies were supposed to increase their funding through public bond issuance rather than relying on captive FILP financing. The reform, however, was inadequate in two respects. First, it provided a generous transition period during which money could continue to flow as it had in the past. Second, it did not contain any provisions for shutting down money-losing public corporations. Without such provisions, market discipline cannot take hold. Indeed, Doi and Hoshi find that the flow of funds through the FILP has not changed much.

Another goal is to limit the distortions for the private sector associated with the continued operation of the money-losing government-sponsored agencies. For instance, the pricing of government loans and deposits could be set to match the rates charged by the private firms. A current proposal to charge for deposit insurance on postal savings accounts would be a useful move in this direction. Another pro-competitive move would be to add prepayment penalties for government-agency loans. The general principle should be that if these kinds of agencies are to continue to operate, they should do so on a level playing field with the private sector.

\section{Conclusion}

There are different reasons for the sizable losses lurking in Japan's banking, insurance, and government agency sectors. Yet, the problems in these sectors are inter-related. The banking problems that attract so much attention will persist until the troubles in the other two sectors are also addressed. A satisfactory resolution requires recognition of the different driving factors behind the problems in all three sectors and would include measures that address all at the same time.

The combined effect of all the problems is huge. Representative estimates for the banking problems are roughly $¥ 40$ trillion. I have argued that most of the losses for the insurance companies will not be borne by the taxpayers, but the FILP losses look to be at least $¥ 78.3$ trillion. Thus, Japanese taxpayers are likely on the hook for roughly $¥ 120$ trillion (24 percent of GDP)!

A variety of factors have contributed to the delay in confronting the problems. One huge problem is the government's unwillingness to force the restructuring that will be necessary to create a profitable banking sector. The restructuring will lead to business closures and job losses in the banking sector. Another serious problem is the lack of political will to shut down or restructure the popular, but unprofitable government-sponsored 
financial agencies. These organizations are especially problematic since they further impair the competitiveness of the private sector.

The recent bail out of Daiei Inc., a large bankrupt grocery store chain, shows how difficult this will be. Daiei had $¥ 420$ billion of its debt restructured in January 2002 by its three major lenders. However, it was soon clear that the restructuring plan was insufficient (since Daiei still had $¥ 1.7$ trillion in debt) and that the banks would need to accept more losses. In October, the Japan Development Bank came forward and offered $¥ 10$ billion as part of a second restructuring plan (that included another $¥ 50$ billion from the private banks). The move was hailed by the government as helping to protect the 96,000 Daiei employees as the restructuring continued.

But this tack is likely to be counterproductive in several respects. One problem is that it sets a bad precedent for future cases. The banks are already routinely rolling over loans rather then pulling the plug on bankrupt firms, because if the banks did recognize the losses they would be at risk for having too little capital and being shut down. Banks will have even less reason to recognize losses and take them when there is the chance that government assistance will be offered.
More importantly, the bailouts (and routine rollovers) that keep the deadbeat borrowers in business also distort competition. Other firms that could enter an industry or gain market share are held back. As Caballero, Hoshi, and Kashyap (2002) explain, suppressing the normal process of creative destruction leaves all banks with fewer good borrowers to lend to. Absent good borrowers, the banks have an even greater incentive to roll over loans to deadbeat borrowers. As the cycle progresses, the firms continue to lose money and increase the banks' losses.

Ironically, therefore, keeping the deadbeats alive likely raises the final costs to the taxpayers. In essence, continuing the lending to firms like Daiei amounts to a covert unemployment compensation program. But continuing to funnel the money through the banks creates other costly distortions. Because this stifles the creation of new jobs, there will be fewer alternatives for the displaced workers and less tax revenue accumulated to cushion the blow when the firm finally fails or is significantly downsized. It would be cheaper and more efficient to end this cycle promptly with a large-scale, comprehensive intervention.

\section{NOTES}

${ }^{1}$ Because exchanges rates have varied substantially over the last few years, I have opted not to convert figures into foreign currencies. Japanese nominal GDP has been roughly constant at $¥ 500$ trillion for the last few years so I have normalized other figures relative to this benchmark.

${ }^{2}$ I thank Robert DeYoung for calculating these figures from the U.S. call reports.

${ }^{3}$ On April 1, 2002, the Industrial Bank of Japan, Dai-Ichi Kangyo Bank, and Fuji Bank consummated their merger to form Mizuho Bank, the largest bank in the world. See Associated Press Newswires (2002).

${ }^{4}$ Some of the gap is attributable to the slow development of the syndicated lending market in Japan, since loan syndications move revenue from the form of interest payments to fees.

${ }^{5}$ See Credit Suisse First Boston (2002), figure 8.

${ }^{6}$ See Goldman Sachs (2001), p. 77.

${ }^{7}$ ING Barings (2002).

${ }^{8}$ In principle, a slow winding down of the loan problems would give the banks more time to take advantage of the tax credits. But, as I explain below, stretching out the resolution of the problem is likely to lead to more losses. See Goldman Sachs (2002).
${ }^{9}$ The banks issue securities that are bought by the life insurance companies, which effectively buy the securities by turning over their own securities. The net effect is that reported capital may be increased but the amount of real money raised is greatly overstated.

${ }^{10}$ See table 11 of Merrill Lynch (2002).

${ }^{11}$ See table 6 of Daiwa Institute of Research (2002).

${ }^{12}$ See table 3 of Fitch Ratings (2002).

${ }^{13}$ The exact definition is $200 \times$ (net assets/risk), where net assets are defined as the sum of capital, risk reserves, general loan loss reserves, excess reserves over the surrender value of policies, future profits, subordinated debt (and loans), and a correction for deferred taxes. The risk is the sum of business management risk and the square root of squared insurance risk plus squared interest rate plus asset management risk.

${ }^{14}$ Tagaki (2002). 


\section{REFERENCES}

Agosta, Veronica, 2002, "Japan's banks are again among world's biggest," American Banker, June 18, p. 2.

Associated Press Newswires, 2002, "Mizuho, world's biggest bank, makes rough debut as ATMs crash, customers get double billed," New York, April 5.

Bank for International Settlements, 2002, BIS 72nd Annual Report, Basel, Switzerland, July 8.

Bank of Japan, 2002a, "New initiative toward financial system stability," public statement, Tokyo, September 18, available at: www.boj.or.jp/en/seisaku/02/sei0208.htm.

,2002b, “Japan's nonperforming loan

problem," public statement, Tokyo, October 11, available at www.boj.or.jp/en/seisaku/02/sei0210.htm.

, 2002c, "(Reference) The outline of the stock purchasing plan," public statement, Tokyo, October 11, available at www.boj.or.jp/en/seisaku/02/ sei0209b.htm.

Bernanke, Ben, 2000, “Japanese monetary policy: A case of self-induced paralysis?," in Japan's Financial Crisis and its Parallels to U.S. Experience, Ryoichi Mikitani and Adam S. Posen (eds.), Washington, DC: Institute for International Economics.

Caballero, Ricardo J., Takeo Hoshi, and Anil K Kashyap, 2002, “Zombies,” University of Chicago, work in progress.

Credit Suisse First Boston, 2002, "Japanese banks," New York, report, May 20.

Daiwa Institute of Research, 2002, "FY01 results of 10 major life insurers," Tokyo, report, June 10.

Doi, Takero, and Takeo Hoshi, 2003, "Paying for the FILP?," in Structural Impediments to Growth in Japan, Magnus Blomstrom, Jenny Corbett, Fumio Hayashi, and Anil Kashyap (eds.), Chicago: University of Chicago Press, forthcoming.

Fitch Ratings, 2002, “Japanese life insurers: Price volatility hitting solvency," New York, report, August 27.

Fukao, Mitsuhiro, 2003, "Financial sector profitability and double gearing," in Structural Impediments to Growth in Japan, Magnus Blomstrom, Jenny Corbett, Fumio Hayashi, and Anil Kashyap (eds.), Chicago: University of Chicago Press, forthcoming.
Goldman Sachs, 2002, "Bank value depends on slow structural reform," New York, report, April 23. ,2001, "Japanese bank asset quality," New York, report, October 31.

Hayami, Masuru, 2002, “The challenges facing Japan's economy," speech given at the Naigai Josei Chousa Kai (The Research Institute of Japan), Tokyo, July 24.

Hoshi, Takeo, and Anil K Kashyap, 2001, Corporate Financing and Governance in Japan: The Road to the Future, Cambridge, MA: MIT Press. , 1999, “The Japanese banking crisis: Where did it come from and how will it end?," National Bureau of Economic Research, working paper, No. W7250, July.

ING Barings, 2002, "Banks: What happens to capital if deferred tax assets are excluded?," Tokyo, report, April 26.

International Monetary Fund, 2002, "Japan: Staff report for 2002 Article IV consultation," Washington, DC.

Kikkawa, Masahiro, Takeshi Sakai, and Hiroyuki Miyagawa, 2000, "Soundness of the fiscal investment and loan program," in Structural Problems of Japanese Financial System, Mitsuhiro Fukao (ed.), Tokyo: Japan Center for Economic Research, pp. 41-59.

Merrill Lynch, 2002, “Life insurance industry,” New York, report, June 5.

Peek, Joe, and Eric S. Rosengren, 2002, “Corporate affiliations and the (mis)allocation of credit," University of Kentucky, working paper.

Svensson, Lars, 2001, "The zero bound in an openeconomy: A foolproof way of escaping from a liquidity trap," Monetary and Economic Studies, Vol. 19, February, pp. 277-312.

Takagi, Shokichi, 2002, press conference, Financial Services Agency, Tokyo, July 15, available at: www.fsa.go.jp/gaiyoue/tyoukan/e20020715.html. 